\title{
The evolution of the socio-cultural and religious characteristics of cancer patients in Morocco: case of the National Institute of Oncology Rabat
}

Fahd Elkhalloufi ${ }^{1,2^{*}}$, Saber Boutayeb ${ }^{1,2}$, Fouzia Mamouch ${ }^{1}$, Latifa Rakibi ${ }^{1,2}$, Sanae Elazzouzi ${ }^{2}$ and Hassan Errihani ${ }^{1,2}$

\begin{abstract}
Background: In 2020, Morocco recorded more than 59,370 new cases of cancer and more than 35,265 cases of death (International Agency for Research on Cancer, Annual report Morocco, 2020). Cancer is always accompanied by socially constructed, differentiated, and contingent interpretations and practices according to the socio-cultural and religious characteristics of each region. The study aims at describing the evolution of the socio-cultural and religious aspects of Moroccan cancer patients followed at the National Institute of Oncology (NIO) of Rabat between 2010 and 2020.
\end{abstract}

Methods: We have prospectively studied all cancer cases diagnosed at the National Oncology Institute (NIO), Rabat in 2019. We have collected 1102 cases. The data collected was compared with the results of the study carried out in 2010 (1600 cases). Statistical analysis has been assessed by SPSS 20 software and the correlations between sociocultural characteristics were examined using a chi-square test.

(Continued on next page)

\footnotetext{
* Correspondence: elkhalloufi.fahd@hotmail.fr

${ }^{1}$ Faculty of Medicine and Pharmacy, Mohammed V University, Rabat,

Morocco

${ }^{2}$ Department of Medical Oncology, National Institute of Oncology, Rabat,

Morocco
}

(c) The Author(s). 2021 Open Access This article is licensed under a Creative Commons Attribution 4.0 International License, which permits use, sharing, adaptation, distribution and reproduction in any medium or format, as long as you give appropriate credit to the original author(s) and the source, provide a link to the Creative Commons licence, and indicate if changes were made. The images or other third party material in this article are included in the article's Creative Commons licence, unless indicated otherwise in a credit line to the material. If material is not included in the article's Creative Commons licence and your intended use is not permitted by statutory regulation or exceeds the permitted use, you will need to obtain permission directly from the copyright holder. To view a copy of this licence, visit http://creativecommons.org/licenses/by/4.0/ The Creative Commons Public Domain Dedication waiver (http://creativecommons.org/publicdomain/zero/1.0/) applies to the data made available in this article, unless otherwise stated in a credit line to the data. 
(Continued from previous page)

Results: From a socio-economic point of view, almost all patients claim that cancer is a costly disease as well as a disease that leads to a drop in income and the inevitable impoverishment of Moroccan patients. The illiteracy rate is still high; rising from 38\% in 2010 to $42.80 \%$ in 2020. On the psychological level, damage to body image (alopecia, mastectomy, hysterectomy, can lead to stigmatizing and harms the marital relationship. The number of patients experiencing divorce and marital separation that seems to occur following cancer pathology remains high, despite a decrease of nearly 50\% between 2010 and 2020. Concerning the spiritual aspect, in the Arab-AmazighMuslim culture, the impact of the occurrence of cancer is very particular, and the repercussions are assessed differently depending on the degree of conviction. For practicing believers, cancer is considered a divine test and an opportunity to improve. In the Qur'an, God tests the best of his disciples to reward them The rate of practicing believers has evolved from 49\% in 2010 to $85.50 \%$ in 2020.But for non-practicing believers, cancer is regarded as a divine punishment coming from outside. New behaviors reported by this research concern the use of "roquia". This spiritual cure is considered as an anti-cancer remedy. It uses Allah's words from the holy "qur'an", his faires names and his attributes. $42 \%$ of patients use "roquia". Concerning phytotherapy, there was an increase in the percentage of participants using medicinal plants and even the most harmful plants (Arestiloch, Euphorbia) from $26 \%$ in 2010 to $51.50 \%$ in 2020 .

Conclusion: The precarious social level of cancer patients, the lack of social and medical coverage, illiteracy, and lack of knowledge of religion, as well as dissatisfaction with conventional medicine, may lead patients to the use of traditional medicine (medicinal plants, visit of "marabouts", "roquia"). This can have a negative impact on the quality of access to oncology care.

Keywords: Cancer, Socio-cultural characteristics, Religious characteristics

\section{Background}

In Morocco, cancer is the second leading cause of death, with an estimated incidence rate of 148.30 cases per 100,000 and an estimated mortality rate of 86.90 cases per 100,000. In 2020, Morocco recorded more than 59,370 new cases of cancer. Breast cancer (19.80\%) and lung cancer (12.40\%) were the most common. On the other hand, 35,265 cases of death were recorded [1].

Cancer is accompanied by socially constructed interpretations and practices, differentiated according to the socio-cultural characteristics of each region [2]. Indeed, in Moroccan culture, cancer is synonymous with death [3]. Patients face many challenges [4]. These include family difficulties related to uncertainty about the place and social role or separation from the spouse, and social and professional difficulties related to access to care, social and medical coverage [5].

Several studies conducted at the National Institute of Oncology (INO) in Rabat [2, 6, 7] have shown that certain socio-cultural characteristics can have harmful consequences on the patient and his family environment. $64 \%$ of patients have low incomes, $87 \%$ are unemployed and $83 \%$ have no medical coverage covering the cost of care. This requires doctors to adapt treatment protocols to accord with the financial means and stocks available in the hospital, and not to therapeutic standards that include increasingly expensive drugs (targeted therapies and new chemotherapy drugs).
This has a psychological impact due to the fear of ineffective treatment (fear, anxiety). Difficulties in communication between caregivers and patients, due mainly to illiteracy and the Amazigh dialect, generate not only create anxiety for the patient, but also for the physician, who must ensure therapeutic care alone without the patient being involved. On the other hand, women have a high rate of divorce as a result of cancer. Besides, a survey of sexuality and cancer had revealed that $85 \%$ of couples had sex-related disorders.

Other practices further exacerbate this finding and jeopardize the process of treating patients. These include the visit of "marabouts" and the use of harmful plants that endanger the patient's life, or extremism in the practice of religion in some cancer patients.

With this in mind, this study aims at describing the evolution of socio-cultural and religious characteristics of cancer patients between 2010 and 2020 .

\section{Methods}

This is a comparative cross-sectional study that aims to describe the evolution of the socio-cultural and religious aspects of Moroccan cancer patients followed at the NIO of Rabat between 2010 and 2020. NIO is the leading oncology center in Morocco (in operation since 1985) recruiting more than six thousand new patients per year. Meanwhile, the hospital is a center of reference in oncology in Morocco. The study took place between January 2019 and January 2020. 


\section{Inclusion criteria}

Patient recruitment concerns all patients followed at NIO who have given their written consent to the study through a consent form; must be at least 18 years of age, histologically confirmed cancer regardless of its stage and current or completed treatment.

Before patient recruitment, the descriptive study was approved by the ethics committees of the Faculty of Medicine and Pharmacy of the flap under No. 26/19.

\section{Exclusion criteria}

Patients who do not meet the inclusion criteria abovementioned are excluded from this research, as well as those with diffuse brain metastases that may have an impact on language or intellectual abilities that bias the questioning.

\section{Data collection}

For data collection, we adopted a questionnaire with questions adapted to the main psycho-socio-cultural characteristics of Morocco. The questionnaire was developed in consultation with a multidisciplinary medical team consisting of a psychologist, a sociologist nursing executives, and medical oncologists.

\section{Data analysis}

The data were analyzed using SPSS software and the bibliographic management using ZOTERO software. Qualitative data were summarized by absolute numbers and percentages. Quantitative data were summarized by medians. The statistical analysis consisted of descriptive analysis of the 1102 data and a study of the relationships between the different characteristics.

\section{Results}

One thousand one hundred and twenty-five (1125) cancer patients were enrolled in this study. Of these patients, 23 were ineligible. The reasons for patient ineligibility were as follows: five [8] subjects were in palliative care, 4 subjects did not have sufficient knowledge of the Arabic language, 8 subjects found the questionnaire long enough to answer all the items, and 6 patients did not have time because of the distances they traveled (exhaustion, fatigue).

As a result, one thousand one hundred and two (1102) patients were included in this study. For patients from 2010, 1600 patients were included in this study.

According to the results obtained, in 2020 women represent $78 \%$ of the sample, while in 2010 women represent $57.20 \%$. Regarding marital status, married patients predominate with $73.80 \%$ in 2020 and $52 \%$ in 2010 . The divorce rate was almost declined by $50 \%$ (17\% in 2010 and $8.30 \%$ in 2020). The age of the participants varies between 20 and 92 years. The median age is 51 . The most affected age group is 40-60 (59.62\%), of which $85 \%$ are women.

Islam is the official religion (either in 2010 or 2020). Compared to ethnic groups, the rate of participants of Amazigh origin has decreased by $18.10 \%$ in 2020 and $25 \%$ in 2010 in addition to an increase for nationals of Arab origin (75\% in 2010 and $81.90 \%$ in 2020 ).

There is also an increase in the use of the Arabic language $(75 \%$ in 2010 and $92.40 \%$ in 2020 ) as a spoken language: The spoken language is the Moroccan dialect called "darija", that is to say [9]. It is generally used as a communication tool between Arabic and Amazigh speakers.

The illiteracy rate remains high (38\% in 2010 and $42.80 \%$ in 2020). There is also an improvement for participants arriving at secondary school or higher (7\% in 2010 and $18.40 \%$ in 2020). The educational situation at the rural level is much more deleterious.

\section{Socio-economic characteristics}

According to Table 1, 58.20\% of patients have no income, $28.70 \%$ receive less than the SMIG (legal minimum wage in Morocco), which is $\$ 270$ per month [10], and only $13 \%$ of patients receive a salary above the SMIG. Nevertheless, in $2010,76 \%$ of patients received less than the SMIG.

For basic medical coverage, there is a decline in the rate of patients with no insurance from $83 \%$ in 2010 to $66.20 \%$ in 2020 . In this case, the State shall bear the costs of treatment within the limits of the treatments available in public health establishments. At the same time, there has been an increase in the percentage of participants affiliated with Health Insurance from 12 to $32.10 \%$ between 2010 and 2020 . This mode of insurance is based on the principles of social insurance for the benefit of persons engaged in a remunerated activity (government employees and private sector employees).

Concerning the geographical remoteness of patients. In $2020,68.50 \%$ of patients come from outside the city of Rabat and 28, 90\% from rural areas. In 2010 80\% of patients come from outside the city of Rabat, $70 \%$ of them from rural areas. To access care, NIO patients travel a distance with a median of $80.00 \mathrm{~km}$ in 2020 and $200 \mathrm{~km}$ in 2010. This remoteness imposes expenses for transportation as well as hotel accommodation during treatment or while waiting for an appointment. Nearly $70 \%$ of patients report significant transportation costs exceeding an average of $30 \$$ per treatment session. Add to this the cost of hotels and food. As a result, $66 \%$ of patients turn to their families or associations to ensure their care and/or stay. 
Table 1 Socio-economic characteristics of cancer patients in Morocco

\begin{tabular}{|c|c|c|}
\hline \multirow{3}{*}{$\begin{array}{l}\text { Year } \\
\text { Variable }\end{array}$} & \multirow{3}{*}{$\begin{array}{l}2010 \text { (1600 cases) } \\
\text { Number of cases \% }\end{array}$} & \multirow{3}{*}{$\begin{array}{l}2020 \text { (1102 cases) } \\
\text { Number of cases \% }\end{array}$} \\
\hline & & \\
\hline & & \\
\hline \multicolumn{3}{|l|}{ Sex } \\
\hline Man (male) & $685(42,80 \%)$ & $242(22,00 \%)$ \\
\hline Woman (female) & $915(57,20 \%)$ & $860(78,00 \%)$ \\
\hline \multicolumn{3}{|l|}{ Marital Status } \\
\hline Single & $400(25,00 \%)$ & $122(11,10 \%)$ \\
\hline Married & $832(52,00 \%)$ & $813(73,80 \%)$ \\
\hline Divorced & $272(17,00 \%)$ & $093(08,30 \%)$ \\
\hline Widowed & $096(06,00 \%)$ & $075(06,80 \%)$ \\
\hline \multicolumn{3}{|l|}{ Ethnic Group } \\
\hline Arab & $1200(75,00 \%)$ & $902(81,9 \%)$ \\
\hline Amazigh & $400(25,00 \%)$ & $200(18,1 \%)$ \\
\hline \multicolumn{3}{|l|}{ Spoken Langauge } \\
\hline Arabic & $1120(75,00 \%)$ & $1018(92,4 \%)$ \\
\hline Amazigh & $480(25,00 \%)$ & $0082(7,40 \%)$ \\
\hline Frensh or English & $000(00,00 \%)$ & $0002(0,20 \%)$ \\
\hline \multicolumn{3}{|l|}{ Level of education } \\
\hline Illiterate & $608(38,00 \%)$ & $472(42,80 \%)$ \\
\hline Qurranic & $560(35,00 \%)$ & $195(17,70 \%)$ \\
\hline Primary & $320(20,00 \%)$ & $232(21,10 \%)$ \\
\hline Secondary & $048(03,00 \%)$ & $155(14,10 \%)$ \\
\hline University & $064(04,00 \%)$ & $048(04,30 \%)$ \\
\hline \multicolumn{3}{|l|}{ Social Security } \\
\hline No insurance & $1328(83,00 \%)$ & $724(66,20 \%)$ \\
\hline With Inssurance & $192(12,00 \%)$ & $354(32,10 \%)$ \\
\hline Paid & $080(05,00 \%)$ & $019(01,70 \%)$ \\
\hline \multicolumn{3}{|l|}{ Patient's income } \\
\hline No income & $0224(14,00 \%)$ & $643(58,30 \%)$ \\
\hline Les than $270 \$$ & $1216(76,00 \%)$ & $317(28,70 \%)$ \\
\hline $270 \$$ and more & $0160(10,00 \%)$ & $142(13,00 \%)$ \\
\hline \multicolumn{3}{|l|}{ Provenance } \\
\hline region of Rabat & $0320(20,00 \%)$ & $347(31,50 \%)$ \\
\hline other region & $1280(80,00 \%)$ & 755 (68,50\%) \\
\hline \multicolumn{3}{|l|}{ Place of residence } \\
\hline Urbain & $0400(25,00 \%)$ & $784(71,10 \%)$ \\
\hline Rural & $1200(75,00 \%)$ & $318(28,90 \%)$ \\
\hline \multicolumn{3}{|l|}{ Family support } \\
\hline Yes & Not known & $857(77,80 \%)$ \\
\hline 'Non & Not known & $245(22,20 \%)$ \\
\hline
\end{tabular}

\section{Marital and family relationship}

On the marital level, the divorce rate decreased from $17 \%$ in 2010 to $7.30 \%$ in 2020 . It should be noted that
97\% of divorced participants are women. At the family level, Moroccan society is a solidarity society; solidarity and family support are present in $77,80 \%$ of Moroccan patients. $45 \%$ of them received material assistance. Family support for the patient is essential for his or her adaptation to the disease and treatment, disease management and quality of life [11].

According to the results obtained. In Table 2, the rate of practicing believers rose from $49 \%$ in 2010 to $85.50 \%$ in 2020. The impact of cancer onset varies according to the degree of practice [12]. Among religious believers (85.50\%), cancer is a divine test. It has therefore led to an acceptance of the illness or even pride in being chosen by God. More than half of them become more practicing as a result of their cancer. This behavior is manifested in prayer, reading the Qur'an, and praising God. Some patients adopt rather harsh religious behaviors, even against medical advice, such as fasting (3.40\%), going on a large or small pilgrimage $(0.40 \%)$.

Nevertheless, among the non-practicing, cancer is due to divine punishment. Therefore a sense of guilt among the study population is ingrained in their psyche, as deserve the label of "bad Muslims". This way of thinking engenders an extremist religious practice, and in some cases, this practice goes against medical recommendations (fasting, pilgrimage during treatment). In the two

Table 2 Religious characteristics related to cancer

\begin{tabular}{|c|c|c|}
\hline $\begin{array}{l}\text { Year } \\
\text { Variable }\end{array}$ & $\begin{array}{l}2010(1600 \\
\text { cases) } \\
\text { Number of } \\
\text { cases (\%) }\end{array}$ & $\begin{array}{l}2020(1102 \\
\text { cases) } \\
\text { Number of } \\
\text { cases (\%) }\end{array}$ \\
\hline \multicolumn{3}{|l|}{ Religious customs } \\
\hline Non practicing believer & $816(51,00 \%)$ & $160(14,50 \%)$ \\
\hline Practicing believer & $784(49,00 \%)$ & $942(85,50 \%)$ \\
\hline \multicolumn{3}{|l|}{ Wearing the Veil } \\
\hline Yes & $1088(68,00 \%)$ & $755(68,50 \%)$ \\
\hline No & $0512(32,00 \%)$ & $347(31,50 \%)$ \\
\hline \multicolumn{3}{|l|}{ Visit the marabouts } \\
\hline No & $1296(81,00 \%)$ & $1029(93,40 \%)$ \\
\hline Yes & $0304(19,00 \%)$ & $0073(06,60 \%)$ \\
\hline \multicolumn{3}{|l|}{ Medical Plants } \\
\hline No & $1184(74,00 \%)$ & $534(48,50 \%)$ \\
\hline Yes & $0416(26,00 \%)$ & $568(51,50 \%)$ \\
\hline \multicolumn{3}{|c|}{ Alcohol and Tobacco cessation } \\
\hline No & $0040(23,50 \%)$ & $064(22,00 \%)$ \\
\hline Yes & $0128(76,50 \%)$ & $227(78,00 \%)$ \\
\hline Healthy person & $1432(89,50 \%)$ & $811(73,60 \%)$ \\
\hline \multicolumn{3}{|l|}{ Roquia } \\
\hline No & Not known & $643(58,30 \%)$ \\
\hline Yes & Not known & $459(41,70 \%)$ \\
\hline
\end{tabular}


groups studied, more than $68 \%$ of participants woman systematically wear the veil, either to cover alopecia related to different therapies or to get closer to God.

In both groups, some patients stopped tobacco and drinking alcohol. In 2010, 76.50\% of the patients stopped this behavior after the discovery of the disease. All of them were men. The same pattern is observed in 2020; $78 \%$ of the patients declared quitting these habits.

In addition, "roquia" now appears as an emerging new phenomenon espoused by cancer patients. Nearly $42 \%$ of patients use "roquia" as a remedy. This Spiritual therapy as an unconventional therapeutic practice appears and spreads in a context favored by the religious effervescence associated with the return to an "original" Islam [13]. It is a method of cure based on reading the quranic verses and recitations of the prophet "Sunnah" [14]. The "roquia" is what is said for the purpose of seeking protection and treating cases of illnesses, such as fever and epilepsy. The "roquia" uses Allah's words from the holy "Qur'an", his faires names and his attributes. Also the "roquia" uses the above mentionned in addition the dihkr (the words in allah's remembrance) and established prayers [15].

Similarly, another aspect of Moroccan culture is added to "roquia". This is the visit of the "marabouts". It would have a divine power "albaraka" for those who practice it, whether for the treatment of incurable diseases, mental illnesses, or protection from the evil eye [14]. In our context, $6.60 \%$ of participants do visits to the "marabouts" compared to $19 \%$ in 2010.

Regarding medical Plants, there has been an increase in the percentage of participants using medicinal plants, from $26 \%$ in 2010 to $51.50 \%$ in 2020 . Dozens of plants are thus used in different forms (plant extract, fumigation, mixing with other plants,). The most used plants according to our survey are Saffron, Propolis, Thyme, Oregano, Myrtle, Cypress, Arar, Eucalyptus, Dill, Sagebrush/ Armoise/ Mugwort, Potentilla anserina, Lavender. There are even the most harmful plants (Arestiloch, Euphorbus). More than half of those interviewed use plants mentioned in the Qur'an and the Sunnah: honey, dates, pomegranate and its leaves, nigella, garlic, ginger, olives, and figs.

\section{Discussion}

Cancer leads to a disruption in the patient's life [16]. Different spheres of life are affected: social, family, marital and professional life [17]. Indeed, the evolution of the socio-economic level of patients, from 2010 to 2020 was always negative. Almost all patients claim that cancer is a costly disease, which in addition, leads to a drop in income and the inevitable impoverishment of Moroccan patients [2]. It has also been noted that the illiteracy rate is still high, rising from $38 \%$ in 2010 to $42.80 \%$ in 2020 .
This rate is four times higher among women than among men, which leads to a greater lack of knowledge of medical information by women.

Culturally, cancer is associated with death [4]. It raises questions concerning finitude and death very soon [18]. It causes a "bad death" for all those it affects [19]. This can lead to the stigmatization of people with cancer [20]. This phenomenon appears in several forms. First, damage to body image (alopecia, mastectomy, hysterectomy) can lead to stigmatizing behavior from the immediate environment [17] and avoidance of all social contact and leisure activities [21]. Second, the psychological impact of breast cancer has a dual origin: on the one hand, it is linked to the image of cancer, which signifies suffering, death, and on the other hand, to the image of breasts as a symbol of femininity, motherhood, and sexuality [17].

This harms the marital relationship, as Moroccan women are often dependent on their husbands to cover the costs of care [2]. This social, legal, and economic vulnerability is the cause of greater suffering and distress for a Moroccan cancer patient compared to a male patient. This is illustrated by the large number of female patients who are victims of divorce and separation despite a decrease of almost half of cases between 2010 and 2020. In contrast, in the case of men with cancer, they are often supported by their wives.

On the spiritual level, Cancer is an opportunity to challenge lifestyle and values [22]. It is not surprising that spirituality positively influences health or well-being if it is defined in positive terms [23]. In the Arab-Berber/ Amazigh-Muslim culture, the impact of the onset of cancer is assessed differently according to the degree of belief [2].

For practicing believers, cancer is considered a divine test. It is attributed to the will of the Almighty (God, genius, spirit, etc.) who calls to order those who have strayed from the "right path" by sending them this trial [24]. In the "Qur'an", God tests the best of his disciples to reward them, and the result is an acceptance of illness and even pride in having been chosen by God [2].

In our study, we see an increase in the rate of practicing believers, from $49 \%$ in 2010 to $85.50 \%$ in 2020 . Therefore, feeling supported by one's faith may alleviate the symptoms of depression and anxiety [24]. López and his team [25] showed the place of spirituality in the acceptance of gynecological cancers in women with gynecological cancers that had a high level of spiritual well-being. Paola Lissoni [26] demonstrated a relationship between the degree of spiritual faith and the response to chemotherapy in patients with advanced cancer. Tumour regression, lymphocyte count, and three-year survival were all significantly higher in patients with a high faith score. 
However, another audience views the disease as divine punishment from the outside [20]. It is not uncommon to find that patients attribute their disease to an "educational God" [27]. Divine punishment seems to be particularly prevalent among cancer patients [28].

This new spiritual therapy, "roquia", adopted by some patients, is based on recitations of Qur'anic verses and the invocations taught by the Prophet Muhammad [14]. The patient can treat himself or herself with the help of a therapist of roquia (Raqi). Its users believe that it is effective in dealing with incurable diseases of which cancer is one example. For the Raqis when certain symptoms persist after the patients visited a therapist, who uses modern medicine, they infer that the evil eye or the devils are responsible for that disease [13].

This mode of treatment is not immune to adverse complications in the use of medicinal plants with "roquia" [13]. Indeed, many "Raqis" sometimes draw from the traditional knowledge of plants called remedy of the Arabs "dwa al-'arab", ([29]: 65). For example, they may use harmel (Peganum harmala) which is a powerful purgative toxic to the body [30].

The use of saltwater or seawater with the recitation of the Qur'an is considered a practice that has a purifying virtue without forgetting the danger of salt for hypertensive people. Some "Raqis" use senna leaves ([31] or jujube leaves (sedra, Ziziphus lotus) as strong purgatives while they are toxic for the body [32]. But the most serious is when some patients abandon their treatments, convinced that their ailments can be treated with Roqya [13].

In addition to the plants mentioned, others are used as complementary or anticancer treatments, which doubled in the last decade between 2010 and 2020. Popular beliefs assume that plants are healthier "natural" and can be effective in chemotherapy [33]. Plants are also responsible for a large number of drugs, with fewer side effects.

However, the simultaneous use of these plants is not immune from harmful effects [34]. Medicinal plants may contain toxic substances such as mercury, lead, copper, iron, manganese, nickel, zinc, and arsenic, which can cause serious complications [35]. This is the case of aristolochia (Aristolochia longa L). This species contains aristolochic acid which can cause irreversible renal damage with hematuria and limb paralysis [36]. In addition "Euphorbia resinifera", whose vernacular name is "Daghmous" is widely used to treat cysts [8]. In [37], several cases of intoxicated patients have been reported by the Moroccan Centre for Pharmacovigilance by ingestion of the "Daghmous". Wild garlic (Allium ursinum) does not contain harmful substances but may be confused with poisonous plants [38]. Other effects have been reported, such as acute encephalopathy (in case of overconsumption of saffron), tubulointerstitial nephritis, liver damage, digestive disorders (diarrhea, vomiting, constipation), rectal bleeding [39].

According to Moroccan culture, the visit of "marabouts" has a divine power 'albaraka' where "marabouts" are found for the treatment of incurable diseases or for the treatment of mental illnesses, and others for the treatment of infertility or to protect against the evil eye [14].

This behavior is experiencing a net decrease from $19 \%$ in 2010 to $6.60 \%$ in 2020 . This can be explained by the referral of patients to the "roquia" rather than to the visit of "marabouts", who ask for a lot of financial means ranging from simple gifts to animal sacrificial offerings "sadaka or lahdya" (rooster, sheep, cloth, money..etc.) [40].

\section{Strengths and limitations}

The strengths of this study lie primarily in the sample size of 1102 participants, so the study population was well characterized and more than 70 characteristics were worked on. The results are not necessarily generalizable since the study site is limited to patients followed at $\mathrm{NIO}$ in Rabat. This research concerns the muslim community. it is not generalized to other Christian or Jewish communities. In this study we were limited to the investigation by questionnaire. The comparison between 2010 and 2020 is only for associated socio-cultural and religious characteristics.

\section{Conclusion}

The evolution of the socio-cultural and religious characteristics of Moroccan cancer patients shows a set of difficulties that hinder a better quality of access to oncology care. Indeed, the precarious social level of cancer patients, the lack of social and medical coverage, illiteracy, the upset psychological state (stigmatization, lack of selfesteem), and lack of knowledge of religion, as well as dissatisfaction with conventional medicine, may lead patients to the use of traditional medicine (medicinal plants, visit of "marabouts", "roquia") [39].

All these practices are left to the legislative, scientific, and academic oblivion. This can have harmful complications on the health of patients. As a solution, first of all, the generalization of basic medical coverage, as well as the generalization of social coverage, can ensure access to oncology care. Medicinal plants must obey strict standard rules that only the specialist in herbal medicine can meet. This necessarily implies the regulation of the profession in our country Morocco. The use of "roquia" or marabou visits must be controlled by the state. The involvement of the family circle, as a care partner, can also play an important role in the care of the patient. 


\section{Abbreviations}

IARC: International agency for research on cancer; NIO: National institute of oncology; SMIG: Salaire minimum légal; WHO: World health organization; SPSS: Statistical Package for Social Science; AMFROM: the Moroccan association for training in medical oncology

\section{Acknowledgements}

We would like to thank the Director of $\mathrm{NIO}$ for his permission to publish this article, AMFROM, also Faculty of Medicine and pharmacy Rabat, University Mohamed 5 (UM5) Rabat. All the participants who were involved in this study. And I quote: the health care staff that collected the data. The data collection sites. My thesis supervisor and my co-supervisor.

\section{Authors' contributions}

FE exploited the data, analyzed the data, performed statistical analyses, and wrote and edited the manuscript; FM and LR co-exploited the data and wrote the manuscript; SB and SE contributed to the review and critical writing of the manuscript; HE designed and coordinated the study, and wrote the manuscript. All authors approved the final manuscript for publication.

\section{Funding}

The publication charge of this research will be covered by Moroccan association for training in medical oncology (AMFROM). It played no role in the design of the study and collection, analysis, and interpretation of data and in writing the manuscript.

\section{Availability of data and materials}

The datasets generated and/or analysed during the current study are not publicly available due [The data of participating patients remain confidential and anonymous in the informed consent with the patient. All patients' data are available and archived in our institute] but are available from the corresponding author on reasonable request

\section{Declarations}

\section{Ethics approval and consent to participate}

The protocol of study was approved by the biomedical research Ethics Committee, Faculty of Medicine and Pharmacy Rabat and was conducted with respect to legal aspects under Number 26/19.

For all patients who agree to participate in the study, a written consent was obtained from all patients before they were enrolled in the study.

\section{Consent for publication}

Not applicable.

\section{Competing interests}

The authors have declared not having any competing interests.

\section{Received: 18 August 2020 Accepted: 12 April 2021}

\section{Published online: 07 May 2021}

\section{References}

1. International Agency for Research on Cancer. 2020: Annual report Morocco: https://gco.iarc.fr/today/data/factsheets/populations/504-morocco-factsheets.pdf

2. Errihani H, Mrabti H, Sbitti Y, Kaikani W, El Ghissassi I, Afair S, et al. Impact psychosocial et religieux du diagnostic de cancer chez les patients marocains : expérience de l'Institut national d'oncologie de Rabat. Bull Cancer. 2010;97(4):461-8. https://doi.org/10.1684/bdc.2010.1082.

3. Saillant F. Cancer et culture: produire le sens de la maladie. Chicoutimi: J.-M. Tremblay; 2009. https://doi.org/10.1522/030165410.

4. Saillant F. Le cancer comme symbole de mort (note de recherche). Anthropologie et Sociétés. 1982;6(3):91. https://doi.org/10.7202/006100ar.

5. Chouaïd C, de Torcy M, Boudjemaa A, Ben Hassen I, Vinas F. Déterminants sociaux et cancer du poumon. Revue des Maladies Respiratoires Actualités 2017;9(2):332-7. https://doi.org/10.1016/S1877-1203(17)30065-4

6. Errihani H, Abarrou N, Ayemou A, El Mesbahi O, El Mazghi A, Marzouki A, et al. Caractéristiques pychosociales des patients atteints de cancers marocains : étude de 1000 cas recrutés à l'Institut national d'oncologie de Rabat. RevFrancophPsycho-oncologie. 2005;2:80-5.
7. Errihani H, Mrabti H, Boutayeb S, El Ghissassi I, El Mesbahi O, Hammoudi M, et al. Impact of cancer on Moslem patients in Morocco. Psycho-Oncology. 2007;17(1):98-100 [PubMed] [Google Scholar].

8. Bouiamrine EH, Bachiri L, Ibijbijen J, Nassiri L. Use of medicinal plants in middle atlas of Morocco: potential health risks and indigenous knowledge in a Berber community. J Med Plants Stud. 2017;5(2):338-42.

9. Caubet D, Miller C. Quels enjeux sociopolitiques autour de la darija au Maroc?. Presses Universitaires de Rouen et du Havre. Langues et mutations sociales au Maghreb, 2016, 979-10-240-0629-9. (halshs-01471125).

10. Achour, Aya and Chafik, Omar, (2019), Salaire minimum au Maroc: faits stylisés et impacts économiques, No 2019-3, Document de travail, Bank AlMaghrib, Département de la Recherche, https://EconPapers.repec.org/RePEc: ris:bkamdt:2019_003.

11. Reich M. Comment le facteur culturel est-il considéré en psycho-oncologie ? Psycho-Oncologi. 2008;2(4):200-9. https://doi.org/10.1007/s11839-008-0096-7.

12. Aggoun Atmane, "Les musulmans, leur corps, la maladie et la mort ", Emmanuel Hirsch éd., Traité de bioéthique. II - Soigner la personne, évolutions, innovations thérapeutiques. Toulouse, "Espace éthique - Poche ", 2010, 120-134. doi: https://doi.org/10.3917/eres.hirsc.2010.02.0120. https:// www.cairn.info/traite-de-bioethique-2\%2D\%2D9782749213064-page-120. htm

13. Cherak F-Z. La roqya, une forme d'automédication chez les possédés et les ensorcelés (Algérie, Égypte, France) ? Anthropologie \& Santé. 2019, mis en ligne le 13 mai 2019, consulté le 18 mars 2021. http://journals.openedition.org/a nthropologiesante/5101. https://doi.org/10.4000/anthropologiesante.5101.

14. Marouf, N. and Codesria. Les IdentitĖs RĖgionales et La Dialectique Sud-Sud En Question. Codesria Book Series. Codesria, 2007. https://books.google.sn/ books?id=zVsYIh1nSMIC

15. Ibn hajar's Fat-hul-Baari, pp. 4/534-535 and p.10/207.

16. Derogatis LR, Morrow GR, Fetting J, et al. The prevalence of psychiatric disorders among cancer patients. JAMA. 1983;249(6):751-7. https://doi.org/1 0.1001/jama.1983.03330300035030.

17. Reich M. Cancer et image du corps : identité, représentation et symbolique: Travail présenté lors des 27es Journées de la Société de I'Information Psychiatrique, Lille 24-27 septembre 2008. L'information psychiatrique. 2009; 85(3):247. https://doi.org/10.3917/inpsy.8503.0247.

18. da Rocha G, Roos P, Shaha M. Le sentiment de finitude de vie et les stratégies de coping face à l'annonce d'un cancer. Revue internationale de soins palliatifs. 2014;2(2):49-53. https://doi.org/10.3917/inka.142.0049.

19. Moulin P. Imaginaire social et Cancer. Revue Francophone de PsychoOncologie. 2005;4(4):261-7. https://doi.org/10.1007/s10332-005-0094-y.

20. Pujol, J.-L. " Les représentations sociales et individuelles du cancer du poumon ". Revue de Pneumologie Clinique 65 (2009): S3-6.doi: https://doi. org/10.1016/S0761-8417(09)72496-4.

21. McKenzie F, White CA, Kendall S, Finlayson A, Urquhart M, Williams I. Psychological impact of colostomypouch change and disposal. Br J Nurs. 2006;15(6):308-1. https://doi.org/10.12968/bjon.2006.15.6.20678.

22. Claire Boileau, "Raymond Massé, Culture et Santé Publique. Les contributions de l'anthropologie à la prévention et à la promotion de la santé ". Face à face 1999, mis en ligne le 01 septembre 1999, consulté le 19 mars 2021. http:// journals.openedition.org/faceaface/469

23. Balboni M, Puchalski C, Peteet J. The relationship between medicine, Spirituality and Religion: Three Models for Integration. J Religion Health. 2014:53. https://doi.org/10.1007/s10943-014-9901-8.

24. Pujol N. Spiritualité et cancérologie: Enjeux éthiques et épistémologiques d'une intégration. 2014. http://www.theses.fr/2014PA05D015/document.

25. López AJ, McCaffrey R, Quinn Griffin MT, Fitzpatrick JJ. Spiritual well-being and practices among women with gynecologic cancer. Oncol Nurs Forum. 2009;36(3):300-5. https://doi.org/10.1188/09.ONF.300-305.

26. Lissoni P, Messina G, Parolini D, Balestra A, Brivio F, Fumagalli L, et al. A spiritual approach in the treatment of cancer: relation between faith score and response to chemotherapy in advanced non-small cell lung cancer patients. In Vivo. 2008;22(5):577-81 PMID: 18853749.

27. Eckhard F. L'accompagnement des malades cancéreux. Un défi pour la psychothérapie. Études. 2006;405:485-95. https://doi.org/10.3917/etu.055.04 85 https://www.cairn.info/revue-etudes-2006-11-page-485.htm.

28. Morin M, Souville M, Moatti JP, Obadia Y. 1995. "Stigmatization Process and Obstacles to Commitment in Care for HIV Patients Among GP's". In: Friedrich D, Morin M, editors. "Perspectives de recherches pour l'étude empirique de l'explication sociale des maladies". Psychologie française, vol. 41-2; 1996. p. 147-54. 
29. Shabou A. De la maladie dans le Sud-Tunisien. Actualité d'une représentation. In: LONGUENESSE E. (dir.), Santé, médecine et société dans le monde arabe. Paris: L'Harmattan; 1995. p. 59-84.

30. Hermas J, Hassani LMI. Effets de l'alimentation En Peganum harmala L. (Zygophyllaceae) Sur Le Tube Digestif Du Criquet Pèlerin Schistocerca Gregaria Forsk. (Orthoptera, Acrididae). Zoologica Baetica. 2008;19:71-84.

31. Derbré S, Leclerc M-V. Prise en charge des vomissements, diarrhées et constipation par les thérapeutiques complémentaires et alternatives. Actualités Pharmaceutiques. 2014;53(534):47-52. https://doi.org/10.1016/j.a ctpha.2014.01.010.

32. Rsaissi N, Bouhache M, Bencharki B. Allelopathic potential of Barbary fig " Opuntia ficus-indica (L.) Mill " on the germination and growth of wild jujube Ziziphus lotus (L.) Desf. Int J Innov Appl Stud. 2013;3(1):205-14.

33. Despres C., Couralet P-E, Situation testing : the case of health refusal, Revue d'epidémiologie et de santé publique. 2011:59(2):77-89.

34. Ernst E. Harmless herbs? A review of the recent literature. Am J Med. 1998; 104(2):170-8. https://doi.org/10.1016/S0002-9343(97)00397-5.

35. Vončina $M$, Baričevič $D$, Brvar M. Adverse effects and intoxications related to medicinal/harmful plants. Acta agriculturae Slovenica. 2014;103(2):263-70. https://doi.org/10.14720/aas.2014.103.2.10.

36. Mazars, Guy. "Pharmacopée traditionnelle du Maroc : Jamal Bellakhdar, La Pharmacopée marocaine traditionnelle. Médecine arabe ancienne et savoirs populaires." Revue d'histoire de la pharmacie, 86e année, N. 320, 1998., 1998. https://www.persee.fr/doc/pharm_0035-2349_1998_num_86_320_4719_t1_ 0465_0000_3.

37. le Centre Anti Poison et de Pharmacovigilance du Maroc (CAPM), 2013. Toxicovigilance rapports général et spécifiques http://www.capm-sante.ma/ uploads/documents/43.pdf

38. Pilegaard K. (n.d.). Ramson confusable with poisonous plants. 4.

39. Chebat A, Skalli S, Errihani H, Boulaâmane L, Mokrim M, Mahfoud T, et al. Étude de prévalence des effets indésirables liés à l'utilisation des plantes médicinales par les patients de l'Institut National d'Oncologie, Rabat. Phytothérapie 12:25-32. n 1 (février 2014). https://doi.org/10.1007/s10298013-0828-4.

40. Kuczynski L. Attachement, blocage, blindage. Cahiers d'études africaines. 2008, mis en ligne le 08 avril 2011, consulté le 18 mars 2021. URL : http:// journals.openedition.org/etudesafricaines/10552:189-90. https://doi.org/10.4 000/etudesafricaines.10552.

\section{Publisher's Note}

Springer Nature remains neutral with regard to jurisdictional claims in published maps and institutional affiliations.

Ready to submit your research? Choose BMC and benefit from:

- fast, convenient online submission

- thorough peer review by experienced researchers in your field

- rapid publication on acceptance

- support for research data, including large and complex data types

- gold Open Access which fosters wider collaboration and increased citations

- maximum visibility for your research: over $100 \mathrm{M}$ website views per year

At $\mathrm{BMC}$, research is always in progress.

Learn more biomedcentral.com/submissions 